\title{
BENCHMARKING W PODEJŚCIU PROCESOWYM W PRZEDSIĘBIORSTWIE - WYBRANE ZAGADNIENIA
}

W literaturze z zakresu pomiaru wyników i dokonań organizacji wskazuje się na efektywne wykorzystanie systemu pomiaru wyników jako krytycznego czynnika na drodze związanej ze wzrostem konkurencyjności. W tym kontekście, organizacje dokonały redefinicji zakresu i roli tych systemów, aby wzmocnić swoją pozycję konkurencyjną na wybranych rynkach.

Benchmarking jest procesem ciagłego mierzenia i porównywania procesów biznesowych realizowanych $\mathrm{w}$ organizacji $\mathrm{z}$ procesami biznesowymi liderów na całym świecie, celem uzyskania informacji, które pomogą organizacji podjąc działania mające na celu poprawę jej wyników. Aby benchmarking był efektywnym narzędziem, musi koncentrować się na procesach biznesowych, które wpływają bezpośrednio na satysfakcję klientów, a tym samym na wyniki finansowe. Przedsiębiorstwa próbują zintegrować wysiłki związane $\mathrm{z}$ benchmarkingiem $\mathrm{z}$ praktykami w zakresie pomiaru wyników w jeden całościowy system zarządzania benchmarkingiem wyników.

$\mathrm{W}$ artykule zaprezentowano istotę benchmarkingu i podejścia procesowego $\mathrm{W}$ przedsiębiorstwie, relacje jakie mogą między nimi zachodzić oraz wskazano na możliwości zastosowania benchmarkingu $\mathrm{w}$ podejściu procesowym. Przedstawione rozważania autorów prowadzą do wniosku, że w zależności od podejścia, można wyróżnić cztery typy relacji między benchmarkingiem i koncepcją podejścia procesowego w przedsiębiorstwie: benchmarking jest częścią podejścia procesowego, benchmarking jest narzędziem wspomagającym podejście procesowe, koncepcje benchmarkingu i podejścia procesowego występują w przedsiębiorstwie niezależnie, benchmarking jest metodą zarządzania wspomagającą podejście procesowe. Teoretyczne rozważania motywowane są ostatnimi istotnymi zmianami, które wywierają wpływ na współczesne organizacje. Głównym motorem zmian organizacyjnych jest rosnące zainteresowanie podejściem procesowym w zarządzaniu przedsiębiorstwem, którego stosowanie jest ułatwione dzięki postępowi informacyjnemu i komunikacyjnemu.

Słowa kluczowe: benchmarking, proces, podejście procesowe, zarządzanie procesami biznesowymi.

\section{WPROWADZENIE}

Współczesne organizacje stale poszukują nowych podejść do zarządzania, które przyczynią się do zwiększania efektywności i skuteczności realizowanych działań. Nieprzewidywalne i labilne otoczenie, a równocześnie złożone kluczowe warunki rozwojowe współczesnych przedsiębiorstw oraz tempo zmian w gospodarce powodują, że przedsiębiorstwa nie mogą polegać wyłącznie na własnych pomysłach, rozwiązaniach i doświadczeniach.

\footnotetext{
${ }^{1}$ Mgr Magdalena Szydełko (autor korespondencyjny), Katedra Systemów Zarządzania i Logistyki, Wydział Zarządzania, Politechnika Rzeszowska, e-mail: mszydel@prz.edu.pl, al. Powstańców Warszawy 8, 35-959 Rzeszów, tel. (17) 8651493.

${ }^{2}$ Mgr Łukasz Szydełko, Zakład Finansów i Bankowości, Wydział Zarządzania, Politechnika Rzeszowska
} 
Analizując literaturę i opinie praktyków zarządzania, można się spotkać ze stanowiskiem, że najpewniejszym kluczem do sukcesu jest podobieństwo do liderów. Jak podkreślają Christopher E. Bogan i Michael J. English: „Ci, którzy polegają wyłącznie na sobie, są skazani na wieczne wyważanie otwartych drzwi, zamiast uczyć się i korzystać z postępów innych"3. Naprzeciw tym oczekiwaniom wychodzi benchmarking, którego „kwintesencją jest uczenie się poprzez zapożyczanie od najlepszych i adaptowanie ich pomysłów do własnej rzeczywistości"4.

Zdaniem Stanisława Nowosielskiego, jedną z ważniejszych orientacji w zakresie organizacji i zarządzania współczesnymi jednostkami organizacyjnymi jest podejście procesowe ${ }^{5}$. Procesy funkcjonują w każdej organizacji, niezależnie od tego, czy najwyższe kierownictwo uświadamia sobie ich istnienie, czy też nie. Według Agnieszki Bitkowskiej coraz więcej organizacji reorganizowanych jest właśnie pod kątem procesów, ponieważ ich efektywność przekłada się na efektywność systemu jako całoścí.

Zorientowanie przedsiębiorstwa na procesy jest niewątpliwie przedsięwzięciem bardzo skomplikowanym, przede wszystkim dlatego, że systemy organizacyjne większości przedsiębiorstw mają charakter funkcjonalny. Orientacja przedsiębiorstwa na funkcje, komórki organizacyjne i szczegółowy podział pracy jest mocno zakorzeniona w praktyce zarządzania i świadomości kierownictwa. Innymi barierami we wdrażaniu rozwiązań procesowych są wysoki koszt projektowania organizacji procesowej, które często wspierane jest przez firmy konsultingowe, oraz opór pracowników wobec zmian organizacyjnych. Projektowanie i konfiguracja organizacji procesowej oznacza poruszanie się po gruncie słabo jeszcze rozpoznanym zarówno przez praktyków, jak i teoretyków zarządzania.

Celami artykułu są przedstawienie istoty koncepcji benchmarkingu i podejścia procesowego $\mathrm{w}$ zarządzaniu przedsiębiorstwem oraz pokazanie relacji zachodzących między nimi w kontekście możliwości wykorzystania benchmarkingu w podejściu procesowym. Intencją autorów jest wprowadzenie do tematyki benchmarkingu, który może znaleźć zastosowanie $\mathrm{w}$ podejściu procesowym $\mathrm{w}$ przedsiębiorstwach, a także przedstawienie złożoności tego zagadnienia oraz najistotniejszych wniosków, które będą miały wpływ na dalsze badania prowadzone przez autorów niniejszego opracowania w tej tematyce w przyszłości. Postawione cele determinują wybór metody badawczej, jaką jest analiza i krytyka piśmiennictwa.

\section{ISTOTA I ZAKRES BENCHMARKINGU}

$\mathrm{Na}$ początku lat dziewięćdziesiątych ubiegłego wieku polscy menedżerowie przechodzili przyspieszony kurs zarządzania, ucząc się tej sztuki od menedżerów z krajów rozwiniętych. Zmiany, jakie zaszły w polskiej gospodarce po 1989 roku, przyczyniły się do rozwoju różnych koncepcji i metod zarządzania w przedsiębiorstwach, między innymi benchmarkingu.

${ }^{3}$ Ch.E. Bogan, M.J. English, Benchmarking jako klucz do najlepszych praktyk, Helion, Gliwice 2006, s. 15. ${ }^{4}$ Ibidem, s. 18.

${ }^{5}$ Podejście procesowe w organizacjach, red. S. Nowosielski, „Prace Naukowe Uniwersytetu Ekonomicznego” 2009/52, s. 11.

${ }^{6}$ A. Bitkowska, Zarzadzanie procesami biznesowymi w przedsiębiorstwie, Vizja Press \& IT, Warszawa 2009, s. 39. 
Etymologicznie benchmarking wywodzi się od słowa benchmark, a jego językowe korzenie tkwią w geodezji, gdzie benchmark (punkt niwelacyjny, reper) był wyraźnym znakiem wykonanym na ścianie lub budynku, czyli służył za punkt odniesienia przy wyznaczaniu lokalizacji lub wysokości obiektu nad poziomem morza w pomiarach topografii terenu i pływów oceanicznych ${ }^{7}$. Zatem słowo to jest najczęściej interpretowane jako punkt orientacyjny, odniesienia lub norma, według której dana rzecz może zostać zmierzona i oceniona.

W literaturze i praktyce funkcjonuje wiele definicji benchmarkingu, w których podkreśla się inne cele i zadania. Nie ma zgody co do tego, czym jest benchmarking: metoda, narzędziem, techniką czy procesem. W naukach o zarządzaniu benchmarking definiowany jest najczęściej jako instrument, dzięki któremu możliwe jest porównywanie się $\mathrm{z}$ najlepszymi. Narzędzie to umożliwia przeorientowanie się przedsiębiorstwa na organizację będącą wzorcem jakości i produktywności ${ }^{8}$. Warto również podkreślić, że benchmarking jest utożsamiany ze zbiorem procedur i technik, pozwalających na dokonywanie porównań $\mathrm{z}$ liderami wewnątrz i na zewnątrz przedsiębiorstwa, odpowiednio ukierunkowanych na uczenie się i twórcze wykorzystanie doświadczeń wyniesionych z najlepszych praktyk ${ }^{9}$. Inna definicja benchmarkingu, sformułowana przez American Productivity and Quality Centre, brzmi następująco: „benchmarking jest procesem mierzenia i porównywania organizacji z innymi na całym świecie $\mathrm{w}$ celu uzyskania informacji o najlepszej filozofii, praktykach i środkach, które pomogą danej organizacji podejmować działania na rzecz jej doskonalenia"10.

Inne wybrane definicje benchmarkingu przedstawiono $\mathrm{w}$ tabeli 1.

Tabela 1.Wybrane definicje benchmarkingu

\begin{tabular}{|c|c|}
\hline Autor & Definicja benchmarkingu \\
\hline $\begin{array}{l}\text { Robert C. } \\
\text { Camp }\end{array}$ & $\begin{array}{l}\text { Benchmarking jest poszukiwaniem najefektywniejszych metod dla } \\
\text { danej organizacji pozwalających osiągnąć przewagę konkurencyjną }\end{array}$ \\
\hline $\begin{array}{l}\text { BengtKarlöf } \\
\text { SvanteÖstblom }\end{array}$ & $\begin{array}{l}\text { Benchmarking (porównywanie się z najlepszymi) to ciągły i } \\
\text { systematyczny proces polegający na konfrontowaniu własnej } \\
\text { efektywności mierzonej produktywnością, jakością i } \\
\text { doświadczeniem z wynikami tych przedsiębiorstw i organizacji, } \\
\text { które można uznać za wzór doskonałości }\end{array}$ \\
\hline $\begin{array}{l}\text { TonyBendell } \\
\text { LouiseBoulter }\end{array}$ & $\begin{array}{l}\text { Benchmarking to jednoczesne przyglądanie się funkcjonowaniu } \\
\text { przedsiębiorstwa i obserwowanie lepszych od siebie w poszukiwaniu } \\
\text { rozwiązań, które można od nich zapożyczyć. Stanowi on integralną } \\
\text { częśc procesu poprawy i nie kończy się zchwilą dokonania porównań } \\
\text { i uznania, że przedsiębiorstwo działa dobrze lub wykazuje straty. } \\
\text { Należy rozważyć metody przeniesienia nowych koncepcji na grunt } \\
\text { przedsiębiorstwa, możliwość ich udoskonalenia i wdrożenia }\end{array}$ \\
\hline Christopher E. & Benchmarking to proces nieustannego poszukiwania najlepszych \\
\hline
\end{tabular}

\footnotetext{
${ }^{7}$ http://www.merriam-webster.com (dostęp: 30.03.2013).

${ }^{8}$ B. Jasiński, Benchmarking, [w:] Zarzadzanie przedsiębiorstwem przyszłości. Koncepcje, modele, metody, red. K. Perechuda, Placet, Warszawa 2000, s. 105.

${ }^{9}$ B. Nita, Rachunkowość w zarządzaniu strategicznym przedsiębiorstwem, WoltersKluwerBusiness, Warszawa 2008, s. 357.

${ }^{10} \mathrm{http}: / /$ www.apqc.org (dostęp: 30.03.2013).
} 


\begin{tabular}{|l|l|}
\hline Bogan & praktyk, które po zaadaptowaniu i wdrożeniu w danej organizacji \\
Michael J. & mogą skutkować doskonała wydajnością. W benchmarkingu trzeba \\
English & położyć nacisk na ciagłość i kompleksowość działań mających na \\
& $\begin{array}{l}\text { celu zidentyfikowanie najlepszych praktyk operacyjnych, które po } \\
\text { wdrożeniu pomogą uzyskać doskonałe wyniki }\end{array}$ \\
\hline
\end{tabular}

Źródło: opracowanie własne na podstawie: R.C. Camp, Business Process Benchmarking. Finding and Implementing Best Practices, ASQC Quality Press, Milwaukee, Wisconsin 1995, s. 77; B. Karlöf, S. Östblom, Benchmarking - równaj do najlepszych, Biblioteka Menedżera i Bankowca, Warszawa 1995, s. 7; T. Bendell, L. Boulter, Benchmarking, Wydawnictwo Profesjonalnej Szkoły Biznesu, Kraków 2000, s. 21; Ch.E. Bogan, M.J. English, Benchmarking jako klucz do najlepszych praktyk, Helion, Gliwice 2006, s. 19.

$\mathrm{Na}$ tle przedstawionych definicji benchmarkingu zostanie zaprezentowana jeszcze własna propozycja autorów. Benchmarking jest to instrument zarządzania, który wykorzystywany jest do ciagłego porównywania własnych rozwiązań z najlepszymi praktykami wewnątrz lub na zewnątrz przedsiębiorstwa w celu twórczego ich adaptowania dla osiągnięcia założonych celów.

Dokonując klasyfikacji benchmarkingu, można zastosować dwa najczęściej spotykane w literaturze kryteria:

- podmiotowe (wzorzec),

- przedmiotowe.

W niniejszej pracy autorzy zaproponowali również nowe kryterium, jakim jest częstotliwość stosowania koncepcji benchmarkingu.

Szczegółowe charakterystyki poszczególnych rodzajów benchmarkingu przedstawiono w tabeli 2 .

Tabela 2.Klasyfikacje benchmarkingu

\begin{tabular}{|c|c|}
\hline Kryterium & Rodzaje benchmarkingu \\
\hline $\begin{array}{l}\text { Kryterium } \\
\text { wzorca }\end{array}$ & $\begin{array}{l}\text { - Benchmarking wewnętrzny -polega na przeprowadzaniu } \\
\text { porównań procesów, metod działania i operacji w obrębie } \\
\text { tego samego przedsiębiorstwa (wzorcem może być inny } \\
\text { dział, wydział, filia, oddział) } \\
\text { - Benchmarking zewnętrzny z konkurencją -polega na } \\
\text { przeprowadzaniu porównań procesów, funkcji, metod } \\
\text { działania, operacji i produktów z bezpośrednimi } \\
\text { konkurentami i jest na ogół trudny do stosowania ze } \\
\text { względu na problemy ze znalezieniem partnera i dostępem } \\
\text { do poufnych danych. } \\
\text { - Benchmarking zewnętrzny funkcyjny -polega na } \\
\text { przeprowadzaniu porównań obszarów funkcjonalnych } \\
\text { (produkcji, zaopatrzenia, dystrybucji, marketingu, } \\
\text { magazynowania itd.)z przedsiębiorstwami niebędącymi } \\
\text { bezpośrednimi konkurentami }\end{array}$ \\
\hline $\begin{array}{l}\text { Kryterium } \\
\text { przedmiotu }\end{array}$ & $\begin{array}{l}\text { - Benchmarking operacyjny zorientowany na procesy -polega } \\
\text { na przeprowadzaniu porównań pojedynczych procedur i } \\
\text { procesów operacyjnych zazwyczaj z partneramiz zewnątrz. } \\
\text { Przykłady porównywanych procesów to: realizacja }\end{array}$ \\
\hline
\end{tabular}




\begin{tabular}{|c|c|}
\hline & $\begin{array}{l}\text { zamówień, logistyczna obsługa klienta, transport } \\
\text { wewnętrzny } \\
\text { - Benchmarking operacyjny zorientowany na wyniki - } \\
\text { pozwala menedżerom ocenić pozycję konkurencyjną } \\
\text { przedsiębiorstwa poprzez: porównywanie produktów, } \\
\text { koncentrowanie się na przykład na składnikach ceny, } \\
\text { jakości produktów (parametrach), prowadzenie analiz } \\
\text { porównawczych innych wskaźników, na przykład czasu i } \\
\text { kosztu wytworzenia wyrobu, niezawodności obsługi klienta, } \\
\text { szybkości dostarczenia wyrobu do klienta, rentowności, } \\
\text { zysku operacyjnego, przychodów ze sprzedaży } \\
\text { - Benchmarking strategiczny -polega na poszukiwaniu } \\
\text { skutecznych strategii, które zapewniają przedsiębiorstwom } \\
\text { doskonałe wyniki i sukcesy. W przeciwieństwie do } \\
\text { poprzednichdwóch rodzajów benchmarkingu obejmujących } \\
\text { działalność operacyjną przedsiębiorstwa, pozwala na ocenę } \\
\text { jego zdolności do konkurowania,ponieważ jestzasadniczą } \\
\text { częścią planowania strategicznego, a korzyści jego } \\
\text { stosowania nie ujawniają się natychmiast }\end{array}$ \\
\hline $\begin{array}{l}\text { Kryterium } \\
\text { częstotliwości }\end{array}$ & $\begin{array}{l}\text { - Benchmarking doraźny -polega na przeprowadzaniu } \\
\text { jednorazowych porównań i szukaniu najlepszych rozwiązań } \\
\text { dopiero w momencie wystąpienia problemów czy zagrożeń } \\
\text { w działalności przedsiębiorstwa lub pogorszenia się wyniku } \\
\text { finansowego } \\
\text { - Benchmarking ciągły -w przeciwieństwie do } \\
\text { jednorazowego benchmarkingu, jest on wpisany w proces } \\
\text { systematycznego doskonalenia przedsiębiorstwa i } \\
\text { przyczynia się do ciągłej poprawy wyników } \\
\text { przedsiębiorstwa. Ze względu na wysokie koszty jego } \\
\text { stosowania i konieczność zaangażowania znacznych } \\
\text { zasobów znajduje on zastosowanie w średnich i dużych } \\
\text { przedsiębiorstwach }\end{array}$ \\
\hline
\end{tabular}

Źródło: opracowanie własne.

Rozwiązania w zakresie benchmarkingu stosowane przez przedsiębiorstwa diametralnie się różnią ze względu na dwuznaczność, niejasność i zagadkowość tego pojęcia $^{11}$. Niektóre przedsiębiorstwa poszukują konsorcjów partnerskich, w ramach których mogą dzielić się ze sobą doświadczeniami, inne koncentrują się na powierzchownych kontaktach $\mathrm{z}$ liderami w danej branży w celu kopiowania ich metod działania, a jeszcze inne zatrudniają konsultantów, których zadanie polega przede wszystkim na porównywaniu wyników działalności (głównie finansowych) przedsiębiorstwa $\mathrm{z}$ konkurentami. Innymi źródłami informacji na potrzeby benchmarkingu przedsiębiorstw są prasa, telewizja, radio, Internet, targi, konferencje,

\footnotetext{
${ }^{11}$ T. Bendell, L. Boulter, Benchmarking, Wydawnictwo Profesjonalnej Szkoły Biznesu, Kraków 2000, s. 19.
} 
Monitor Polski B, wyspecjalizowane instytucje, na przykład agencje ratingowe i wywiadownie gospodarcze.

\section{PODEJŚCIE PROCESOWE WSPOMAGANE BENCHMARKINGIEM}

$\mathrm{Na}$ wstępie należy przedstawić definicję procesu i istotę podejścia procesowego. W normie PN-EN ISO 9000:2006 proces zdefiniowano jako „każde działanie lub zbiór działań, w których wykorzystuje się zasoby do przekształcenia wejść w wyjścia" ${ }^{12}$.Definicję tę można rozszerzyć, stwierdzając, że proces jest zbiorem następujących po sobie działań, które przekształcają zasoby wejściowe w wyjściowe, dzięki czemu powstaje wartość dodana dla klienta i organizacji. Według Piotra Grajewskiego każdy zbiór czynności można przedstawić jako proces, który powoduje, że z pewnego nakładu otrzymujemy rezultat, czyli nakład wzbogacony o wartość dodaną 13 .

Podejście procesowe w praktyce zarządzania polega na:

1) zidentyfikowaniu procesów realizowanych w organizacji i działań (czynności, operacji) składających się na poszczególne procesy,

2) określeniu powiązań między procesami (zależności przyczynowo-skutkowych),

3) określeniu celów poszczególnych procesów,

4) stosowaniu odpowiednich metod monitorowania (nadzoru) i mierzenia procesów,

5) zapewnieniu dostępności zasobów rzeczowych, ludzkich, finansowych i informacyjnych potrzebnych do prawidłowego przebiegu procesów,

6) określeniu danych wejściowych (zasileń), danych wyjściowych (rezultatów), dostawców i odbiorców,

7) określeniu odpowiedzialności za przebieg i wynik poszczególnych procesów,

8) ciąłym doskonaleniu procesów (wdrażaniu działań doskonalących) na podstawie wyników monitorowania (pomiaru) i rzetelnych analiz ${ }^{14}$.

Analizując literaturę, można stwierdzić, że nie ma jednoznacznego stanowiska co do relacji między benchmarkingiem i podejściem procesowym. Zdaniem autorów niniejszego opracowania, mogą wystąpić, w zależności od podejścia kierownictwa przedsiębiorstwa, cztery typy powiązań między nimi:

a) benchmarking jest częścią koncepcji podejścia procesowego,

b) benchmarking jest instrumentem wspomagającym podejście procesowe,

c) benchmarking i podejście procesowe występują w przedsiębiorstwie niezależnie,

d) benchmarking jest metodą zarządzania wspierającą podejście procesowe.

Autorzy opracowania stoją na stanowisku, że benchmarking można uznać za instrument (narzędzie) wspomagający podejście procesowe, pod warunkiem że koncepcję benchmarkingu stosuje się w przedsiębiorstwie wyłącznie na jego potrzeby. Jeżeli jednak kierownictwo przedsiębiorstwa traktuje benchmarking jako integralną część procesu (filozofii) ciągłego doskonalenia i element swojej strategii, wówczas powinien zostać uznany za metodę zarządzania, służącą do wprowadzania najlepszych praktyk w każdym obszarze przedsiębiorstwa, poprzez porównania $\mathrm{z}$ najlepszymi rozwiązaniami stosowanymi wewnątrz, przez konkurencję lub inne porównywalne przedsiębiorstwa.

\footnotetext{
${ }^{12}$ PN-EN ISO 9000:2006 - Systemy zarzqdzania jakościa - Podstawy i terminologia, Polski Komitet Normalizacyjny, Warszawa 2006, s. 13.

${ }^{13}$ P. Grajewski, Organizacja procesowa. Projektowanie i konfiguracja,PWE, Warszawa 2007, s. 55.

${ }_{14}$ M. Szydełko, Podejście procesowe w zarzqdzaniu jakościa - studium przypadku, „Zeszyty Naukowe Politechniki Rzeszowskiej” 2010/4, s. 169.
} 
Należy podkreślić, że benchmarking można zastosować zarówno na etapie wdrażania podejścia procesowego, jak i $\mathrm{w}$ trakcie jego funkcjonowania $\mathrm{w}$ przedsiębiorstwie. W pierwszym wypadku kierownictwo będzie mogło zaadaptować najlepsze (wzorcowe) rozwiązania i praktyki, na przykład w zakresie przygotowania harmonogramu wdrażania podejścia procesowego, projektowania organizacji zorientowanej na procesy, identyfikacji i modelowania procesów, monitorowania i mierzenia procesów, controllingu procesów, systemu informatycznego wspierającego zarządzanie procesami.

W drugim wypadku benchmarking (zarówno strategiczny, jak i operacyjny) może być narzędziem przydatnym w doskonaleniu różnych procesów, działań, metod i systemów, wdrożonych na potrzeby podejścia procesowego w przedsiębiorstwie.

Szczególnym rodzajem benchmarkingu jest benchmarking procesów. Oznacza on najczęściej porównywanie procesów oraz procedur w przedsiębiorstwach (z punktu widzenia wybranych kryteriów) ${ }^{15}$. Najczęściej celem jego wdrożenia jest wprowadzenie na poziomie zarządzania procesowego najlepszych praktyk w wymiarze strategicznym i operacyjnym. Uwzględnienie różnych kryteriów porównań pozwala wyodrębnić strategiczny i operacyjny benchmarking procesów. Analizę porównawczą przedstawiono w tabeli 3 .

Tabela 3.Porównanie strategicznego i operacyjnego benchmarkingu procesów

\begin{tabular}{|l|l|l|}
\hline $\begin{array}{l}\text { Kryterium } \\
\text { porównania }\end{array}$ & \multicolumn{1}{|c|}{$\begin{array}{c}\text { Strategiczny } \\
\text { benchmarking procesów }\end{array}$} & \multicolumn{1}{|c|}{$\begin{array}{c}\text { Operacyjny } \\
\text { benchmarking procesów }\end{array}$} \\
\hline Cel stosowania & $\begin{array}{l}\text { Wsparcie tworzenia i realizacji } \\
\text { strategii w przedsiębiorstwach } \\
\text { zorientowanych procesowo }\end{array}$ & $\begin{array}{l}\text { Wsparcie w operacyjnym } \\
\text { podnoszeniu efektywności } \\
\text { procesów }\end{array}$ \\
\hline Orientacja & $\begin{array}{l}\text { Procesy występujące } \\
\text { u konkurentów lub } \\
\text { w przedsiębiorstwach } \\
\text { działających w odmiennych } \\
\text { branżach }\end{array}$ & $\begin{array}{l}\text { Procesy występujące } \\
\text { w przedsiębiorstwie } \\
\text { zorientowanym procesowo }\end{array}$ \\
\hline Źródła danych & $\begin{array}{l}\text { Konkurenci, przedsiębiorstwa } \\
\text { działające w innych branżach, } \\
\text { wywiadownie gospodarcze }\end{array}$ & $\begin{array}{l}\text { Przedsiębiorstwo } \\
\text { zorientowane procesowo }\end{array}$ \\
\hline Charakter danych & Dane głównie jakościowe & Dane głównie ilościowe \\
\hline Sposób oceny & $\begin{array}{l}\text { Zgodność z założeniami } \\
\text { w formie opisu }\end{array}$ & $\begin{array}{l}\text { Wyniki (dokonania) na } \\
\text { poziomie procesów }\end{array}$ \\
\hline Mierniki & $\begin{array}{l}\text { Najczéściej brak wskaźników, } \\
\text { porównanie na podstawie opisu }\end{array}$ & $\begin{array}{l}\text { Wskaźniki opisujące wyniki, } \\
\text { np. koszty i czas procesów }\end{array}$ \\
\hline
\end{tabular}

Źródło: opracowanie własne na podstawie: R. Kowalak, Rachunek kosztów cyklu życia produktu w zarzadzaniu przedsiębiorstwem, Wydawnictwo UE we Wrocławiu, Wrocław 2009, s. 202-203; M. Sierpińska, B. Niedbała, Controlling operacyjny w przedsiębiorstwie, PWN, Warszawa 2003, s. 57.

\footnotetext{
15 R. Kowalak, Benchmarking jako metoda zarzadzania wspomagajaca controlling przedsiębiorstwa, Wydawnictwo UE we Wrocławiu, Wrocław 2009, s. 20.
} 


\section{PODSUMOWANIE}

Pomyślny przebieg benchmarkingu na każdym etapie wdrażania i stosowania podejścia procesowego w przedsiębiorstwie w znacznym stopniu zależy od:

a) rodzaju prowadzonej działalności i stopnia skomplikowania realizowanych procesów,

b) posiadanej wiedzy przez kierownictwo o benchmarkingu, metodach porównywania, źródłach informacji i korzyściach jego stosowania,

c) kompetencji osób realizujących proces mierzenia i porównywania różnych praktyk i wyników z innymi i zaangażowania pracowników w ten proces,

d) odpowiedniego systemu motywacyjnego,

e) gotowości do partnerstwa $\mathrm{w}$ benchmarkingu, czyli wzajemnie korzystnej wymiany informacji na temat najlepszych praktyk $w$ zakresie podejścia procesowego, prowadzącej do poprawy wyników wszystkich zaangażowanych stron.

Warto w tym miejscu również przytoczyć przesłanie Williama E. Deminga E. Deminga, do którego część kadry zarządzającej nadal nie przykłada dostatecznej wagi: wielu z nas wciąż jest za bardzo skrępowanych przyziemną walką o przetrwanie, by móc się zmierzyć ze strategicznymi i długofalowymi rozwiązaniami systemowymi ${ }^{16}$.

Reasumując rozważania na temat benchmarkingu i podejścia procesowego, należy stwierdzić, że benchmarking rozumiany jako ciagły i systematyczny proces porównywania, nastawiony na twórcze naśladowanie najlepszych praktyk innych jednostek w dowolnej dziedzinie, powinien być elementem strategii każdej organizacji i powinien zostać zintegrowany ze stosowanym podejściem procesowym.

\section{LITERATURA}

[1] Bendell T., Boulter L., Benchmarking, Wydawnictwo Profesjonalnej Szkoły Biznesu, Kraków 2000.

[2] Bitkowska A., Zarządzanie procesami biznesowymi w przedsiębiorstwie, Vizja Press \& IT, Warszawa 2009.

[3] BoganCh.E., English M.J., Benchmarking jako klucz do najlepszych praktyk, Helion, Gliwice 2006.

[4] CampR.C., Business Process Benchmarking. Finding and Implementing Best Practices, ASQC Quality Press, Milwaukee, Wisconsin 1995.

[5] Grajewski P., Organizacja procesowa. Projektowanie i konfiguracja, PWE, Warszawa 2007.

[6] http://www.apqc.org (dostęp: 30.03.2013).

[7] http://www.merriam-webster.com (dostęp: 30.03.2013).

[8] Jasiński B., Benchmarking, [w:]Zarzqdzanie przedsiębiorstwem przyszłości. Koncepcje, modele, metody, red. K. Perechuda, Placet, Warszawa 2000.

[9] Karlöf B., Östblom S., Benchmarking - równaj do najlepszych, Biblioteka Menedżera i Bankowca, Warszawa 1995.

[10] Kowalak R., Benchmarking jako metoda zarzadzania wspomagajaca controlling przedsiębiorstwa, Wydawnictwo UE we Wrocławiu, Wrocław 2009.

[11] Kowalak R., Rachunek kosztów cyklu życia produktu $w$ zarzqdzaniu przedsiębiorstwem, Wydawnictwo UE we Wrocławiu, Wrocław 2009.

[12] Nita B., Rachunkowość $w$ zarzqdzaniu strategicznym przedsiębiorstwem, WoltersKluwerBusiness, Warszawa 2008.

[13] PN-EN ISO 9000:2006 - Systemy zarzqdzania jakościq - Podstawy i terminologia, Polski Komitet Normalizacyjny, Warszawa 2006.

\footnotetext{
${ }^{16}$ Za: T.Bendell, L. Boulter, Benchmarking, Wydawnictwo Profesjonalnej Szkoły Biznesu, Kraków 2000, s. 15.
} 
[14] Podejście procesowe w organizacjach, red. S. Nowosielski, „Prace Naukowe Uniwersytetu Ekonomicznego" 2009/52.

[15] Sierpińska M., Niedbała B., Controlling operacyjny w przedsiębiorstwie, PWN, Warszawa 2003.

[16] Szydełko M., Podejście procesowe w zarzqdzaniu jakościq - studium przypadku, „Zeszyty Naukowe Politechniki Rzeszowskiej” 2010/4.

\section{BENCHMARKING IN PROCESS ORIENTED APPROACH IN THE ENTERPRISE - SELECTED ISSUES}

The performance measurement literature has advocated the effective utilization of performance measurement systems as a critical factor in the road toward competitiveness. In this context, organizations have redefined the scope and the role of these systems in order to enhance competitive position in their selected markets.

The benchmarking is a process of continuously measuring and comparing an organization's business processes against business process leaders anywhere in the world to gain information which will help the organization take action to improve its performance. To be effective benchmarking must concentrate on business processes, that have a direct effect on customer satisfaction and therefore the bottom line. Organizations are attempting to integrate benchmarking efforts with performance measurement practices into an overall organizational benchmarking performance management system. As such, benchmarking is considered as one of the most effective continuous improvement tools.

The article presents selected issues of the benchmarking and process approach in management and describes relationships between them. Depending on the approach, we can specify four types of relationships between benchmarking and process approach in enterprise: benchmarking is part of the process approach, benchmarking is a tool for supporting process approach, benchmarking and process approach are independent in enterprise, benchmarking is a method of management for supporting process approach. The theoretical considerations are motivated by the significant recent changes influencing modern organizations. The principal engine of the organizational changes is the growing interest of the Business Process Management facilitated by information and communication advancements.

Keywords: benchmarking, process, process approach, Business Process Management.

DOI: $10.7862 /$ rz.2013.mmr.23

Tekst złożono w redakcji: maj 2013

Przyjęto do druku: wrzesień 2013 